УДК 340.111.5

DOI https://doi.org/10.32837/pyuv.v2i3(28).375

П.О.Яковлев

кандидат юридичних наук,

докторант

Харківського національного університету імені В. Н. Каразіна

\title{
ВЗАЄМОДІЯ СУБ'ЄКТІВ ПУБЛІЧНОГО УПРАВЛІННЯ ТА ІНСТИТУТІВ ГРОМАДЯНСЬКОГО СУСПІЛЬСТВА В ЗАБЕЗПЕЧЕННІ ІНФОРМАЦІЙНОЇ БЕЗПЕКИ УКРАЇНИ
}

В умовах сьогодення для кожної розвиненої демократичної держави світу важливе гарантування інформаційної безпеки. Здатність системи публічного управління адекватно реагувати на виклики і загрози в інформаційній сфері життедіяльності суспільства є запорукою стабільності функціонування владних інституцій, громадянської злагоди, відсутності інформаційного грунту для поширення антисоціальних ідей та ідеологій.

Для України гарантування інформаційної безпеки - особливо важливе завдання державної політики. Причиною цього є нестабільність військово-політичної ситуації в окремих регіонах держави і загострення геополітичної обстановки у Східній Європі. Отже, останні кілька років українське суспільство неодноразово стикалося 3 інформаційними диверсіями та поширенням інформації, що дискредитує діяльність владних інституцій, а також перешкоджає функціонуванню життєво важливих об'єктів інфраструктури [1]. За таких умов система державного управління, включаючи правоохоронні органи, цілеспрямовано працює над реалізацією комплексних управлінсько-правових, технічних, гуманітарно-культурних, економічних заходів гарантування інформаційної безпеки України. Навіть більше, у 2015 р. в Україні було засновано Міністерство інформаційної політики, одним з основних завдань якого стали забезпечення інформаційного суверенітету і захист інформаційного простору держави від зовнішнього інформаційного впливу [2]. Очевидним $€$ те, що ефективність заходів гарантування інформаційної безпеки України буде вищою за умови налагодження партнерських відносин між суб'єктами публічного управління й інститутами громадянського суспільства, які часто мають у своєму розпорядженні значні інформаційні ресурси.

Беручи до уваги викладене вище, актуальним завданням юридичної науки є доктринальне розроблення аспектів участі громадянського суспільства в заходах, спрямованих на убезпечення інформаційного середовища України від шкідливих посягань.

Метою статті є висвітлення організаційноправових форм взаємодії суб'єктів публічного управління й інститутів громадянського суспільства в питаннях гарантування інформаційної безпеки України.
На теперішній час, згідно із чинним законодавством України, забезпечення інформаційного суверенітету й інформаційної безпеки України $є$ одним із пріоритетних напрямів діяльності держави, складовою частиною гарантування національної безпеки України [3]. Варто зазначити, що заходи з гарантування інформаційної безпеки розробляють і реалізують багато мілітарних і немілітарних суб'єктів органів влади: Президент України, Рада національної безпеки і оборони, Кабінет Міністрів України, місцеві органи влади, органи Міністерства внутрішніх справ, Служба безпеки України, Збройні сили України й ін. Здебільшого повноваження таких органів у сфері інформаційних відносин визначені на рівні законодавства. Що ж стосується участі інститутів громадянського суспільства в реалізації заходів, спрямованих на відвернення інформаційних ризиків і загроз національним інтересам України, то в цій площині є підстави констатувати фактичну неурегульованість цього аспекту.

У площині нормативного визначення в Україні не регламентовано вичерпну кількість інститутів громадянського суспільства. Зокрема, відповідно до п. 2 Порядку сприяння проведенню громадської експертизи діяльності органів виконавчої влади, затвердженого постановою Кабінету Мiністрів України № 976 від 5 листопада 2008 р., до кола інститутів громадянського суспільства віднесено: громадські організації, професійні та творчі спілки, організації роботодавців, благодійні та релігійні організації, органи самоорганізації населення, недержавні засоби масової інформації та інші непідприємницькі товариства й установи, легалізовані відповідно до законодавства [4]. На сьогодні національна практика розвитку інститутів громадянського суспільства свідчить про значну їх кількість. Незважаючи на це, тривалий час у новітній історії України інститути громадянського суспільства певним чином сприяли системі публічного управління в гарантуванні інформаційної безпеки. Проте таке сприяння мало здебільшого спонтанний характер, здійснювалося в межах реалізації загального правового статусу неурядовими організаціями, засобами масової інформації, об'єднаннями громадян тощо. Так чи інакше, але інститути громадянського суспільства формували інформаційне поле держави, що, 
як наголошує А. Турчак, в епоху постінформаційного суспільства багато в чому визначає економічну потужність держави та потребує особливого захисту [5, с. 47$]$.

Ситуація 3 адміністративно-правовим унормуванням інформаційної взаємодії громадянського суспільства і держави докорінно змінилася у 2018 р., коли Указом Президента України було введено в дію рішення Ради національної безпеки і оборони України від 29 грудня 2018 р. «Про Доктрину інформаційної безпеки України» (далі - Доктрина) [6]. У Доктрині визначено, що для гарантування інформаційної безпеки держава розраховує також на залучення інститутів громадянського суспільства для виконання цього завдання. У п. 3 документа встановлено, що налагодження ефективної взаємодії органів державної влади й інститутів громадянського суспільства під час формування і реалізації державної політики в інформаційній сфері є життєво важливим інтересом суспільства і держави. Зазначене положення особливо важливе, адже закладає основи для подальшого розвитку і практичної апробації адміністративно-правових форм взаємодії системи державного управління й інститутів громадянського суспільства щодо здійснення заходів, спрямованих на гарантування інформаційної безпеки України.

Доктрина також визначає кілька адміністративних форм взаємодії державного управління й інститутів громадянського суспільства у сфеpi інформаційної безпеки України. Зокрема, це: спільна протидія інформаційній агресії проти України та надання інформаційної підтримки Україні в реалізації комерційної, гуманітарної, просвітницької, культурної й іншої діяльності за межами України. Варто зауважити, що зазначене вище передбачає виконання складних i багатоступеневих інформаційних функцій як уповноваженими державними органами, так і неурядовими об'єднаннями громадян.

Зазначені форми взаємодії суб’єктів публічного управління й інститутів громадянського суспільства також не є чітко регламентованими. Вони втілюються у процесі реалізації правового статусу інститутами громадянського суспільства за умови фактичного управлінського діалогу із суб'єктами публічного управління, які фахово займаються гарантуванням інформаційної безпеки України. Так, громадські об’єднання, відповідно до Закону України «Про громадські об'єднання» від 22 березня 2012 р. № 4572-VI, є важливими суб’єктами інформаційної діяльності, ініціаторами процесів пошуку, збирання, аналізу, перетворення, зберігання, поширення інформації [7]. У порядку попередження актів інформаційної агресії проти України громадські об'єднання можуть вільно обирати засоби і способи добування і поширення інформації. Це може бути усне поширення, вико- ристання друкованих матеріалів, використання засобів масової інформації й Інтернету, використання можливостей теле- і радіокомунікаційного зв'язку тощо. Здобуті інформаційні дані можуть бути спрямовані на спростування неправильної інформації, яка штучно була введена в інформаційний простір із метою дезинформації конкретного адресата або широких верств населення. Одним із прикладів такої взаємодії є діяльність у Львівській і Тернопільській областях неурядової громадської організації «Центр просвітництва та розвитку людини». За домовленістю з Давидівською об'єднаною територіальною громадою Львівської області зазначена вище організація взяла на себе навантаження з реалізації деяких соціальних послуг [8]. Зокрема, представники цієї організації надають молоді інформаційні послуги з різноманітних питань розвитку і реформування територій. Так, інформація базується на аналізі фактів і моніторингу громадської думки, отже, унеможливлює будь-які спроби маніпулювання інформаційними даними.

Окрім зазначеного, у межах спільної протидії інформаційній агресії проти України громадські об'єднання та їх члени мають право звернутися до органів державної влади, місцевого самоврядування та їх посадових осіб відповідно до їхніх функціональних обов'язків із зауваженнями, скаргами та пропозиціями, що стосуються їхньої статутної діяльності, заявою або клопотанням щодо реалізації своїх соціально-економічних, політичних i особистих прав і законних інтересів та скаргою про їх порушення. Такі звернення громадських об'єднань до органів публічного управління є не лише одним 3 офіційних способів налагодження інформаційної взаємодії із системою публічного управління, а й можливістю цільовим способом донести до відома посадових осіб інформацію, яка розрахована на навмисну дискредитацію діяльності органів державної влади та їх посадових осіб.

Деякий внесок у гарантування інформаційної безпеки інститути громадянського суспільства можуть зробити і у процесі участі в розробленні проєктів нормативно-правових актів, що видаються органами державної влади й органами місцевого самоврядування. У цьому контексті інформаційна підтримка громадських об'єднань суб'єктів державного управління у процесі реалізації правотворчої функції буде сприяти повноцінному врахуванню інформації, що відображає справжні інтереси населення або соціальних груп у процесі розроблення нормативно-правових актів.

Інститути громадянського суспільства та система державного управління взаємодіють інформаційно у процесі роботи консультативних, дорадчих та інших допоміжних органів, що утворюються органами державної влади для проведення консультацій із громадськістю (громадські 
наглядові ради). Цілями такої інформаційної взаємодії є підготовка рекомендацій із питань, що стосуються сфери їхньої діяльності. Консультативно-дорадчі органи формуються інституціями громадянського суспільства, які делегують своїх представників до складу дорадчого органу. Саме такі представники є носіями об'єктивної інформації про потреби суспільного розвитку на місцях. Їхня діяльність є запорукою убезпечення посадових осіб від можливої дезінформації у процесі ухвалення управлінських рішень.

Також інститути громадянського суспільства можуть надавати інформаційну підтримку Україні в реалізації комерційної, гуманітарної, просвітницької, культурної й іншої діяльності за межами України. Завдяки цьому підвищується міжнародний імідж України як привабливого партнера для подальшої міжнародної співпраці. Інститути громадянського суспільства широко представлені у складі одного з робочих органів України і Європейського Союзу (далі - СС), який було створено на виконання ст. ст. 469-470 Угоди про асоціацію між Україною та $\mathrm{CC}$ і який має назву «Платформа громадянського суспільства». До складу органа входять представники 15-ти неурядових організацій, які представляють українське суспільство у взаєминах із неурядовими організаціями держав-членів СС. Зокрема, це ГО «Агенція європейських інновацій», Всеукраїнська асоціація «Iнформаційна безпека та інформаційні технології, Ресурсно-аналітичний центр «Суспільство і довкілля» та ін. [9]. На зустрічах представників неурядових організацій делегати від національних інститутів громадянського суспільства доводять до відома європейських партнерів інформацію про різноманітні аспекти організації національної економіки України, політико-правової сфери, гуманітарного сектора тощо.

Отже, сьогодні в Україні спостерігається зростання темпів взаємодії суб'єктів публічного управління й інституцій громадянського суспільства в інформаційній сфері. Навіть більше, темпи взаємодії постійно зростають. В останні роки не- урядові організації та їхні представники довели, що вони можуть бути ефективними партнерами держави у справі гарантування інформаційної безпеки. Але правовий режим їхньої взаємодії залишається неналежним чином урегульованим на рівні законодавства. Отже, перспективним напрямам дослідження вітчизняної юридичної науки $\epsilon$ доктринальне обгрунтування оптимальних форм адміністрування спільної діяльності інститутів громадянського суспільства і держави в напрямі гарантування інформаційної безпеки України.

\section{Jimepamypa}

1. Хакерські атаки в Україні: у Держцентрі кіберзахисту заявляють про можливий початок нової хвилі. РБК-Україна. 24.10.2017. URL: https://www.rbc.ua/ukr/news/hakerskie-ataki-ukrainegostsentre-kiberzashchity-1508857979.html.

2. Положення про Міністерство інформаційної політики України, затверджене постановою Кабінету Мiністрів України від 14 січня 2015 р. № 2. Міністерство інформаиійної політики України : офіційний вебсайт. URL: https://mip.gov.ua/cr/documents/7.html.

3. Про національну безпеку України : Закон України від 21 червня 2018 р. № 2469-VIII. Відомості Верховної Ради України. 2018. № 31. С. 5.

4. Про затвердження Порядку сприяння проведенню громадської експертизи діяльності органів виконавчої влади : постанова Кабінету Міністрів України від 5 листопада 2008 р. № 976. Офіційний вісник України. 2008. № 86. С. 100 . Ст. 2889.

5. Турчак А. Основні складові інформаційної безпеки держави. Аспекти публічного управління. 2019. № 5. T. 7. C. 44-56.

6. Про рішення Ради національної безпеки і оборони України від 29 грудня 2016 р. «Про Доктрину інформаційної безпеки України» : Указ Президента України від 25 лютого 2017 р. № 47/217. Офіційний вісник Президента України. 2017. № 5. С. 15.

7. Про громадські об’єднання : Закон України від 22 березня 2012 р. № 4572-VI. Відомості Верховної Ради України. 2013. № 1. Ст. 1.

8. Надання соціальних послуг : співпраця НУо та органів місцевого самоврядування. Гурт: ресурсний иентр : вебсайт. URL: https://gurt.org.ua/news/ recent $/ 43120 /$.

9. Що таке УС ПГС? Українська сторона Платформи громадянського суспільства Украӥна - $С С$ : вебсайт. URL: https://eu-ua-csp.org.ua/what-is-eu-ua-csp/. 


\section{Анотація}

Яковлєв П.О. Взаємодія суб'єктів публічного управління й інститутів громадянського суспільства в забезпеченні інформаційної безпеки України. - Стаття.

У статті, на основі аналізу положень чинного законодавства України, яке регламентує правовий статус інститутів громадянського суспільства, а також гарантування інформаційної безпеки України системою публічного управління, висвітлено організаційно-правові форми взаємодії державних органів та інститутів громадянського суспільства в питаннях гарантування інформаційної безпеки держави. Акцентовано увагу на тому, що сьогодні чинним законодавством України недостатньо регламентований механізм партнерської співпраці держави і неурядових організацій як потенційних учасників інформаційних відносин. Висвітлено основні форми взаємодії держави й інститутів громадянського суспільства в контексті гарантування інформаційної безпеки держави: спільна протидія інформаційній агресії проти України та надання інформаційної підтримки Україні в реалізації комерційної, гуманітарної, просвітницької, культурної й іншої діяльності за межами України. Обгрунтовано, що зазначені форми співпраці втілюються у процесі реалізації правового статусу інститутами громадянського суспільства за умови фактичного управлінського діалогу із суб'єктами публічного управління, які фахово займаються гарантуванням інформаційної безпеки України. Виокремлено значущість внеску неурядових громадських організацій у протидію інформаційним атакам на Україну i попередження інформаційних диверсій у національному інформаційному просторі. Також наведено і розкрито зміст інших форм сприяння, які можуть надавати інститути громадянського суспільства суб'єктам публічного управління в частині забезпечення інформаційного суверенітету України (подання інформаційних звернень, інформаційна підтримка органів влади у процесі розроблення нормативних актів, організація роботи консультативних наглядових громадських рад при органах державної влади, залучення неурядових організацій до участі в офіційних міжнародних заходах від імені України). Визначено перспективні напрями дослідження вітчизняної юридичної науки щодо доктринального обгрунтування оптимальних форм адміністрування спільної діяльності інститутів громадянського суспільства і держави в напрямі гарантування інформаційної безпеки України.

Ключові слова: Україна, публічне управління, інформаційна безпека, Доктрина інформаційної безпеки, інформаційні відносини, інформаційна агресія, інформаційна підтримка, громадянське суспільство, неурядова організація, управлінський діалог.

\section{Summary}

Yakovliev $P$. O. Interaction of entities of public administration and institutes of civil society in ensuring cyber security of Ukraine. - Article.

In the article, on the basis of analysis of positions of current legislation of Ukraine, that regulates legal status of institutes of civil society, and also providing of informative safety of Ukraine by the system of public management, the legal forms of cooperation of public organs and institutes of civil society are reflected in questions providing of informative safety of the state. Attention is accented on that today by the current legislation of Ukraine regulated not enough is a mechanism of partner collaboration of the state and ungovernmental organizations as potential participants of informative relations. The basic forms of cooperation of the state and institutes of civil society are reflected in the context of providing of informative safety of the state: common counteraction to informative aggression against Ukraine and grant of informative support to Ukraine in realization of commercial, humanitarian, elucidative, cultural and other activity outside Ukraine. Reasonably, that the marked forms of collaboration are incarnated in the process of realization of legal status the institutes of civil society on condition of actual administrative dialogue with the subjects of public management, that professionally engage in providing of informative safety of Ukraine. Meaningfulness of payment of ungovernmental public organizations is distinguished in counteraction to the informative attacks on Ukraine and warning of informative diversions in national informative space. Maintenance over of other forms of assistance, that can give the institutes of civil society the subjects of public management in part of providing of informative sovereignty of Ukraine (presentation of informative appeals, informative support of government bodies in a process to development of normative acts, organization of work of consultative public reviews broker's at public, bringing in of ungovernmental organizations authorities to participating in official international events on behalf of Ukraine).

Perspective directions of research of home legal science are certain in relation to the doctrine ground of the most optimal forms of administration of joint activity of institutes of civil society and state in the direction of providing of informative safety of Ukraine.

Key words: Ukraine, public management, informative safety, Doctrine of informative safety, informative relations, informative aggression, informative support, civil society, ungovernmental organization, administrative dialogue. 